\title{
FAKTOR-FAKTOR YANG DIPERTIMBANGKAN KONSUMEN MEMUTUSKAN MEMBELI DAN MENGGUNAKAN SMARTPHONE MEREK OPPO DI KECAMATAN PALU SELATAN
}

\author{
TRIA WULAN NDARI \\ WAHYUNINGSIH \\ YOBERTH KORNELIUS \\ Prodi Manajemen, Fakultas Ekonomi, Universitas Tadulako \\ Email: triawulandari1945@gmail.com
}

\begin{abstract}
This study aims to determine factors that consumers consider in buying and using smartphones OPPO in South Palu Sub-district. The sampling technique is Accidental Side by selecting 105 people. The analytical tool is factor analysis. Based on the analysis of 21 indicators, the study finds factors that are considered by the consumers when deciding to buy and use a smartphone brand OPPO are: the first factors includes: promotion and price: X3 (Advertising media TV), X12 (promotions convincing), X14 (Prices are affordable), X15 (the physical form of interest), X17 (service center/customer service); the second factor is product quality that includes: X2 (friends suggestion), X6 (sophisticated feature), X10 (superior camera quality), X11 (good product quality), X21 (correspondence between price and quality); the third factor is lifestyle that includes: X1 (family suggestion), X16 (luxury product design), X19 (unique name and easy to remember), X20 (updated trend).
\end{abstract}

Keywords: buying decision and smartphone

\begin{abstract}
Abstrak
Penelitian ini bertujuan untuk mengetahui faktor-faktor yang dipertimbangkan konsumen dalam membeli dan menggunakan smartphone OPPO di Kecamatan Palu Selatan. Teknik pengambilan sampel adalah Accidental Side dengan memilih 105 orang. Alat analisis adalah analisis faktor. Berdasarkan analisis 21 indikator tersebut, studi ini menemukan faktor-faktor yang dipertimbangkan konsumen saat memutuskan untuk membeli dan menggunakan merek smartphone OPPO adalah: faktor pertama meliputi: promosi dan harga: X3 (media iklan TV), X12 (promosi yang meyakinkan ), X14 (Harga terjangkau), X15 (bentuk fisik bunga), X17 (service center / customer service); Faktor kedua adalah kualitas produk yang meliputi: X2 (saran teman), X6 (fitur canggih), X10 (kualitas kamera superior), X11 (kualitas produk yang baik), X21 (korespondensi antara harga dan kualitas); Faktor ketiga adalah gaya hidup yang meliputi: X1 (family suggestion), X16 (desain produk mewah), X19 (nama unik dan mudah diingat), X20 (mengikuti trend masa kini).
\end{abstract}

Kata Kunci: keputusan membeli dan telepon seluler

\section{PENDAHULUAN \\ Latar Belakang Penelitian}

Perkembangan teknologi komunikasi dan teknologi informasi semakin mengalami kemajuan yang pesat. Seiring dengan kemajuan dan perkembangan tersebut menyebabkan pola hidup masyarakat menjadi berubah dari yang semula untuk memenuhi kebutuhan dasar, mengarah pada pemenuhan kebutuhan non dasar, salah satunya dengan komunikasi. Telekomunikasi menjadi sangat penting karena merupakan sarana yang tepat bagi masyarakat untuk berkomunikasi, segala sesuatu yang dikerjakan oleh orang selalu memerlukan informasi yang cepat, tepat, dan akurat. Oleh karena itu sangat diperlukan sarana transformasi dan komunikasi yang handal untuk mewujudkan keinginan tersebut.

Salah satu produk komunikasi yang mempunyai peran vital dalam memenuhi kebutuhan konsumen dibidang komunikasi, khususnya komunikasi wireless adalah produk telepon seluler atau handphone atau ponsel. Windusarah (2015) menyatakan telepon selular merupakan perkembangan dari telepon rumah yang dapat dibawa kemana saja, karena handphone bersifat mobile dan juga 
dapat membantu kegiatan manusia bukan hanya untuk menelpon namun dapat mengirim sms/pesan, internet, mendengarkan musik, bahkan mengabadikan kegiatan manusia dengan teknologi kamera.

Sejak internet mulai booming di indonesia, internet menjadi fitur yang wajib ada dan berubah fungsi dalam ponsel itu sendiri selain digunakan untuk telepon dan SMS. Ponsel juga digunakan sebagai alat komunikasi untuk mencari informasi-informasi dan fitur-fitur terbaru dari internet. Maka tak heran bila ponsel dengan harga paling murah wajib memenuhi tiga syarat yaitu dapat digunakan untuk telepon, SMS, dan internet.

Menurut Lembaga Riset IDC Indonesia, di tahun 2015 jumlah Smartphone yang masuk ke Indonesia mencapai 29,7 juta unit. Bahkan di tahun 2015 penjualan Smartphone di Indonesia menguasai $43 \%$ pasar Smartphone di ASEAN. Faktor yang berjasa atas peningkatan jumlah Smartphone ini adalah semakin meningkatnya kualitas jaringan internet mobile di Indonesia. Selain peningkatan kualitas jaringan internet mobile, harga Smartphone yang semakin terjangkau juga merupakan alasan kuat di balik kenaikan jumlah Smartphone yang masuk ke negara kita. Pasar Smartphone yang tumbuh pesat di Indonesia direspon positif oleh berbagai vendor Smartphone dengan meluncurkan produk - produk baru sebagai upaya meraih pangsa pasar Smartphone yang lebih baik.

OPPO Electronic Crop, Ltd adalah salah satu perusahaan yang ikut andil dalam meramaikan pasar Smartphone. OPPO Electronic Crop, Ltd pertama kali didirikan tahun 2004 sebagai produsen elektronik yang berpusat di Dongguan China. Sebelum menjajaki dan menciptakan teknologi Smartphone, Oppo terlebih dahulu memproduksi peralatan elektronik seperti MP3 Player, Portable media player, LCD TV,eBook, DVD, dan Disc Player, barulah pada tahun 2008 Oppo mulai melakukan inovasi dan memproduksi Smartphone. Pada bulan april 2013 Oppo secara resmi menginjakan kaki di pasar Indonesia. Sebelum menjajaki pasar Indonesia Oppo terlebih dahulu sudah melebarkan sayap dipasar Vietnam, Qatar, Rusia, dan Amerika. Sejak saat itu perusahaan dan manajemen Oppo terus melakukan kegiatan promosi dalam upaya memperkenalkan produk serta kualitas produknya yang dilakukan melalui berbagai media seperti TV, Internet, dan Media cetak.

Alasan memilih produk Oppo Smartphone sebagai objek untuk melakukan penelitian karena Oppo Smartphone adalah suatu produk yang baru saja muncul di Indonesia. Oppo Smartphone adalah salah satu pabrikan handphone yang namanya sudah mulai dikenal dikalangan masyarakat kota Palu khususnya di Kacamatan Palu selatan. Hal ini bisa terlihat dari banyaknya konsumen yang menggunakan produk Smartphone dari Cina ini, tidak hanya remaja-remaja pelajar, tapi orang tua juga banyak yang menggunakan telepon seluler produk cina ini.

\section{Permasalahan Penelitian}

Dari uraian latar belakang penelitian diatas, maka peneliti menarik permasalahan yaitu : Faktor-faktor manakah yang dipertimbangkan konsumen memutuskan membeli dan menggunakan Smartphone merek Oppo di Kecamatan Palu Selatan?

\section{Tujuan Penelitian}

Berdasarkan rumusan masalah di atas, maka tujuan penelitian yang hendak dicapai yaitu untuk mengetahui faktor- faktor manakah yang dipertimbangkan konsumen memutuskan membeli dan menggunakan Smartphone merek Oppo di Kecamatan Palu Selatan.

\section{KAJIAN LITERATUR DAN PENGEMBANGAN HIPOTESIS Pemasaran}

Kotler \& Keller, (2009) mengemukakan bahwa pemasaran adalah suatu fungsi organisasi dan serangkaian proses untuk menciptakan, mengkomunikasikan, dan memberi nilai kepada pelanggan dan untuk mengelola hubungan pelanggan dengan cara yang menguntungkan organisasi dan pemangku kepentingannya.

\section{Perilaku Konsumen}

Perilaku konsumen sebagai tindakan yang langsung terlibat mendapatkan, mengonsumsi, dan menghabiskan produk dan jasa, termasuk proses keputusan yang mendahului dan menyusuli tindakan ini. 


\section{Produk}

Produk adalah sesuatu yang diharapkan dapat memenuhi kebutuhan manusia ataupun organisasi. Produk adalah segala sesuatu yang dapat ditawarkan produsen untuk diperhatikan, diminta, dicari, dibeli, digunakan atau dikonsumsi pasar sebagai pemenuhan kebutuhan dan keinginan pasar yang bersangkutan (Kotler, 2005).

\section{Smartphone}

Ponsel cerdas (Smartphone) adalah telepon genggam yang mempunyai kemampuan dengan penggunaan dan fungsi yang menyerupai komputer. Belum ada standar pabrik yang menentukan arti ponsel cerdas. Bagi beberapa orang, ponsel cerdas merupakan telepon yang bekerja menggunakan seluruh perangkat lunak sistem operasi yang menyediakan hubungan standar dan mendasar bagi pengembang aplikasi.

\section{METODE PENELITIAN}

\section{Metode Pengumpulan Data}

Tehnik pengumpulan data yang digunakan dalam penelitian ini adalah sebagai berikut :

1. Observasi, yaitu metode pendekatan yang digunakan dimana penulis secara langsung melakukan pengamatan di lokasi penelitian kemudian dilakukan pencatatan tentang apa yang sedang diamati.

2. Wawancara, yaitu metode yang dipakai oleh peneliti untuk mengumpulkan informasi mengenai variabel yang diteliti dengan cara tanya jawab secara langsung dengan responden yang menggunakan Oppo Smartphone di Kecamatan Palu Selatan.

3. Kuesioner, merupakan suatu daftar pertanyaan atau pernyataan tentang topik tertentu yang diberikan kepada subyek, baik secara individual atau kelompok untuk mendapatkan informasi tertentu. Dalam hal ini penulis mengedarkan sejumlah daftar pernyataan yang terstruktur kepada responden yang menggunakan Oppo Smartphone untuk di isi.

\section{Uji Instrumen Penelitian}

Dalam penelitian ini skala pengukuran yang digunakan peneliti adalah skala Likert. Menurut Sugiyono (20104) jawaban setiap instrumen yang menggunakan skala Likert mempunyai gradasi dari sangat positif sampai sangat negative

\section{Metode Analisis}

Pada metode analisis ini, yang dianalisis adalah faktor- faktor yang dipertimbangkan konsumen memutuskan membeli dan menggunakan Smartphone merek Oppo di Kecamatan Palu Selatan dalam hipotesis penelitian.

Analisis faktor adalah salah satu alat analisa untuk menyederhanakan hubungan yang kompleks dari macam- macam variabel serta untuk menentukan variabel- variabel yang mempunyai dimensi sama atau serupa. Model analisis faktor secara umum menurut Malhotra (2005) sebagai berikut:

$$
\mathrm{Xi}=\mathrm{Ai} 1 \mathrm{f} 1+\mathrm{Ai} 2 \mathrm{f} 2+\mathrm{Ai} 3 \mathrm{f} 3+\ldots . .+\mathrm{AiMfM}+\mathrm{V} 1 \mathrm{U} 1
$$

\section{Dimana :}

$\mathrm{Xi}=$ Variabel baku ke-1; Aij = Standarisasi koefisien regresi mejemuk yang dilakukan dari variable 1 atas faktor $\mathrm{j} ; \mathrm{F}=$ Faktor biasa; $\mathrm{Vi}=$ Koefisien regresi yang dibakukan dan variabel $\mathrm{i}$ atas faktor unik i; $\mathrm{Ui}=$ Faktor unik untuk variabel $\mathrm{i} ; \mathrm{m}=$ Banyaknya faktor biasa

Faktor-faktor yang unik tidak saling berkorelasi dan tidak berkoerlasi dengan faktor biasa, faktor-faktor biasa sendiri dapat diungkapkan sebagai kombinasi linear dari variabel- variabel yang diamati. Sehingga dapat dirumuskan sebagai berikut :

$$
\mathrm{Fi}=w i 1 \times 1+w i 2 \times 2+w i 3 \times 3+\ldots \ldots+\text { wikxk }
$$


Dimana :

$\mathrm{Fi}$ = Estimasi faktor ke-1; Wi = Bobot atau jumlah koefisien faktor; $\mathrm{k}=$ Banyaknya variabel

\section{HASIL DAN PEMBAHASAN Hasil Penelitian Analisis Faktor Tahap Pertama}

Tahap pertama pada analisis faktor adalah menilai mana saja yang dianggap layak (appropriates) untuk dimasukkan ke dalam analisis selanjutnya. Pengujian ini dilakukan dengan memasukkan semua variabel yang ada kemudian pada variabel-variabel tersebut dilakukan sejumlah pengujian.

Logika pengujian adalah jika sebuah faktor, maka variabel mempunyai kecenderungan mengelompok dan membentuk sebuah faktor, maka variabel tersebut akan mempunyai korelasi yang cukup tinggi dengan variabel yang lain. Sebaliknya, jika variabel dengan korelasi yang lemah dengan variabel yang lain, maka cenderung tidak akan mengelompok.

Hasil pengujian analisis tahap pertama pada 21 faktor-faktor yang dipertimbangkan konsumen memutuskan membeli dan menggunakan Smartphone merek OPPO di kecamatan Palu Selatan dengan menggunakan bantuan Program Komputer SPSS versi 22.0 dapat dilihat nilai Matriks korelasi pada tabel berikut:

Berdasarkan Tabel 4 di atas dapat diketahui bahwa nilai seluruh faktor yang diuji menggunakan analisis faktor telah memenuhi syarat, karena nilai tengah pada pengolahan data pada tahap pertama memiliki nilai $=1.00$ yang memiliki arti bahwa seluruh faktor yang dilakukan pengujian memiliki hubungan yang kuat sehingga dapat dilanjutkan pada analisis selanjutnya.

Selanjutnya, untuk melihat korelasi antara variabel independen dengan memperhatikan tabel Anti-Image Matrices. Nilai yang diiperhatikan adalah MSA (Measure of Sampling Adequacy) dengan nilai 0 hingga 1 dengan ketentuan sebagai berikut : $\mathrm{MSA}=1$, variabel dapat diprediksi tanpa kesalahan oleh variabel yang lain, MSA > 0,5, variabel masih bisa diprediksi dan bisa di analisis lebih lanjut, dan MSA $<0,5$, variabel tidak bisa diprediksi dan tidak bisa dianalisis lebih lanjut dan harus dikeluarkan dari variabel lainnya. Adapun hasil pengujiannya adalah sebagai berikut :

Berdasarkan Tabel 5.6 diatas dapat di ketahui bahwa Nilai MSA dari X1 lebih dari 0,5 yaitu sebesar $0.894, \mathrm{X} 2$ lebih dari 0,5 yaitu $0.836, \mathrm{X} 3$ lebih dari 0,5 yaitu $0.880, \mathrm{X} 4$ lebih dari 0,5 yaitu $0.675, \mathrm{X} 5$ lebih dari 0,5 yaitu 0.648 , X6 lebih dari 0,5 yaitu 0.887 , X7 lebih dari 0,5 yaitu $0.881, \mathrm{X} 8$ lebih dari 0,5 yaitu $0.536, \mathrm{X} 9$ lebih dari 0,5 yaitu 0.608 , X10 lebih dari 0,5 yaitu 0.771 , X11 lebih dari 0,5 yaitu 0.838 , X12 lebih dari 0,5 yaitu $0.836, \mathrm{X} 13$ lebih dari 0,5 yaitu $0.742, \mathrm{X} 14$ lebih dari 0,5 yaitu $0.906, \mathrm{X} 15$ lebih dari 0,5 yaitu 0.846 , X16 lebih dari 0,5 yaitu 0.929 , X17 lebih dari 0,5 yaitu 0.879 , X18 lebih dari 0,5 yaitu 0.705 , X19 lebih dari 0,5 yaitu 0.776 , X20 lebih dari 0,5 yaitu 0.793 , X21 lebih dari 0,5 yaitu 0.850. Hal ini berarti semua variabel masih bisa diprediksi dan bisa di analisis lebih lanjut.

Tahap selanjutnya adalah melihat Nilai KMO and Barlett's Test Tahap pertama dengan hasil pengujian sebagai berikut :

Tabel 4. Nilai KMO and Barlett's Test Tahap Pertama

KMO and Bartlett's Test

\begin{tabular}{|c|r|}
\hline \multicolumn{2}{|c|}{ Kaiser-Meyer-Olkin Measure of Sampling Adequacy. } \\
Approx. Chi-Square & 878.070 \\
Bartlett's Test of Sphericity Df & 210 \\
Sig. & .000 \\
\hline
\end{tabular}

Pada Tabel 4 di atas, diketahui bahwa nilai Kaiser-Meyer-Olkin Measureof Sampling Adequacy (MSA) sebesar 0.824 dengan signifikansi $(0,000)$. Oleh karena angka MSA berada di atas 0,5 maka variabel yang ada dapat di lakukan analisis lebih lanjut. Selanjutnya setiap faktor dianalisis untuk mengetahui mana yang dapat diproses lebih lanjut dan mana yang harus dikeluarkan.

Pengujian selanjutnya pada tahap pertama ini adalah dengan memeriksa nilai Eigenvalues dari analisis faktor yang telah dilakukan. Eigenvalues pada tahap ini menunjukkan bahwa seluruh 
indikator yang dianalisis terbentuk 4 (empat) faktor. Hal ini dapat dilihat berdasarkan Tabel Eigenvalues yang menunjukkan hanya 4 (empat) komponen yang memiliki Eigenvalues diatas 1.00. untuk lebih jelasnya nilai masing-masing Eigenvalues komponen dapat dilihat pada tabel berikut ini:

Tabel 5. Nilai Eigenvalues Tahap Pertama

Total Variance Explained

\begin{tabular}{|c|c|c|c|c|c|c|c|c|c|}
\hline \multirow{2}{*}{ Component } & \multicolumn{3}{|c|}{ Initial Eigenvalues } & \multicolumn{3}{|c|}{$\begin{array}{l}\text { Extraction Sums of Squared } \\
\text { Loadings }\end{array}$} & \multicolumn{3}{|c|}{$\begin{array}{c}\text { Rotation Sums of Squared } \\
\text { Loadings }\end{array}$} \\
\hline & Total & $\begin{array}{c}\% \text { of } \\
\text { Variance }\end{array}$ & $\begin{array}{c}\text { Cumulative } \\
\%\end{array}$ & Total & $\begin{array}{c}\% \text { of } \\
\text { Variance }\end{array}$ & $\begin{array}{c}\text { Cumulative } \\
\%\end{array}$ & Total & $\begin{array}{c}\% \text { of } \\
\text { Variance }\end{array}$ & $\begin{array}{c}\text { Cumulative } \\
\%\end{array}$ \\
\hline 1 & 6.822 & 32.486 & 32.486 & 6.822 & 32.486 & 32.486 & 4.900 & 23.333 & 23.333 \\
\hline 2 & 1.789 & 8.519 & 41.004 & 1.789 & 8.519 & 41.004 & 2.943 & 14.014 & 37.346 \\
\hline 3 & 1.567 & 7.461 & 48.466 & 1.567 & 7.461 & 48.466 & 2.035 & 9.690 & 47.036 \\
\hline 5 & 1.407 & 6.701 & 55.167 & 1.407 & 6.701 & 55.167 & 1.707 & 8.131 & 55.167 \\
\hline 6 & 1.230 & 5.855 & 61.022 & & & & & & \\
\hline 7 & .977 & 4.650 & 65.672 & & & & & & \\
\hline 8 & .890 & 4.236 & 69.908 & & & & & & \\
\hline 9 & .827 & 3.939 & 73.848 & & & & & & \\
\hline 10 & 699 & 3.327 & 77.175 & & & & & & \\
\hline 11 & .663| & 3.159 & 80.334 & & & & & & \\
\hline 12 & .617 & 2.940 & 83.273 & & & & & & \\
\hline $\begin{array}{l}13 \\
14\end{array}$ & .540 & 2.572 & 85.846 & & & & & & \\
\hline $\begin{array}{l}14 \\
15\end{array}$ & .482 & 2.295 & 88.140 & & & & & & \\
\hline 16 & .454 & 2.164 & 90.304 & & & & & & \\
\hline 17 & .430 & 2.047 & 92.351 & & & & & & \\
\hline 18 & .356 & 1.694 & 94.045 & & & & & & \\
\hline 19 & .330 & 1.570 & 95.615 & & & & & & \\
\hline 20 & .284 & 1.350 & 96.965 & & & & & & \\
\hline 21 & .241 & 1.149 & 98.115 & & & & & & \\
\hline & .212 & 1.009 & 99.123 & & & & & & \\
\hline & |.184| & .877 & 100.000 & & & & & & \\
\hline
\end{tabular}

Extraction Method: Principal Component Analysis.

Berdasarkan data pada Tabel 5 diatas, diketahui bahwa terdapat 5 (lima) faktor yang terbentuk pada analisis tahap pertama. Nilai Eigenvalues pada faktor 1 masih diatas 1.00 yaitu sebesar 6.822, pada faktor 2 nilai Eigenvalues juga masih diatas 1.00 yaitu sebesar 1.789, pada faktor 3 nilai Eigenvalues masih diatas 1.00 yaitu sebesar 1.567, faktor 4 nilai Eigenvalues masih diatas 1.00 yaitu sebesar 1.407, faktor 5 nilai Eigenvalues masih diatas 1.00 yaitu sebesar 1.230, sedangkan faktor 6 dengan nilai Eigenvalues sudah berada dibawah 1.00 yaitu sebesar 0.977 sehingga proses factoring berhenti pada faktor 6 (Enam) dan hanya menghasilkan 5 (Lima) faktor saja, namun karena faktornya telah ditentukan dari awal yaitu 4 (empat) faktor, maka proses factoring berhenti pada faktor 5 (lima). Sehingga hanya menghasilkan 4 (empat) faktor.

Tahap selanjutnya adalah pengujian atas matriks faktor. Pengujian terhadap matriks faktor dilakukan dengan membandingkan nilai Component Matrikx pada setiap variabel dengan nilai loading factor. Apabila ditemukan nilai matriks faktor lebih kecil dari nilai loading factor maka faktor tersebut dikeluarkan dari proses factoring karena variabel tidak dapat secara nyata membentuk 
sebuah faktor. Nilai loading factor atau pembatas (cut off point) agar sebuah variabel dapat secara nyata termasuk sebuah faktor, dari data 105 responden yang diperoleh pada penelitian ini adalah sebesar 0,55 .

Untuk lebih jelasnya nilai matriks faktor yang dibandingkan dengan nilai loading factor sebesar 0,55 untuk secara nyata dapat termasuk sebuah faktor, dapat termasuk sebuah faktor, dapat dilihat pada tabel berikut :

Tabel 6. Komponen Matriks Tahap Pertama

Component Matrix ${ }^{a}$

\begin{tabular}{|c|c|c|c|c|}
\hline & \multicolumn{4}{|c|}{ Component } \\
\hline & 1 & 2 & 3 & 4 \\
\hline $\mathrm{X} 1$ & .730 & -.041 & -.060 & .096 \\
\hline $\mathrm{X} 2$ & .748 & -.070 & .007 & -.122 \\
\hline X3 & .641 & -.378 & -.110 & .128 \\
\hline $\mathrm{X} 4$ & .300 & .106 & .771 & .175 \\
\hline X5 & .345 & -.131 & -.342 & .485 \\
\hline X6 & 647 & -.059 & .470 & -.112 \\
\hline X7 & .563 & -.155 & -.057 & -.393 \\
\hline X8 & .327 & .076 & .238 & -.338 \\
\hline X9 & .363 & .502 & -.277 & .262 \\
\hline $\mathrm{X} 10$ & .571 & .464 & .258 & .120 \\
\hline X11 & .655 & .136 & .077 & -.330 \\
\hline $\mathrm{X} 12$ & .654 & -.445 & .099 & .012 \\
\hline $\mathrm{X} 13$ & .346 & .194 & .236 & .567 \\
\hline X14 & .581 & -.212 & -.255 & -.144 \\
\hline X15 & .575 & -.377 & .057 & -.102 \\
\hline $\mathrm{X} 16$ & .727 & .133 & -.161 & -.217 \\
\hline X17 & .785 & -.159 & -.097 & .253 \\
\hline $\mathrm{X} 18$ & .306 & .647 & .045 & -.224 \\
\hline X19 & .548 & .289 & -.232 & .001 \\
\hline X20 & .560 & .339 & -.418 & -.069 \\
\hline X21 & .555 & -.095 & .106 & .329 \\
\hline
\end{tabular}

Berdasarkan tabel 6 di atas, dapat diketahui bahwa terdapat beberapa indikator yang memiliki nilai matriks faktor dibawah ini nilai loading factor yaitu indikator F4 memiliki nilai loading factor kurang dari 0.55 yaitu sebesar 0.300, untuk indikator F5 memiliki nilai loading factor kurang dari 0.55 yaitu sebesar 0.345 , untuk indikator F8 memiliki nilai loading factor kurang dari 0.55 yaitu sebesar 0.327, untuk indikator F9 memiliki nilai loading factor kurang dari 0.55 yaitu sebesar 0.363 , untuk indikator F13 memiliki nilai loading factor kurang dari 0.55 yaitu sebesar 0.346 . untuk indikator F13 memiliki nilai loading factor kurang dari 0.55 yaitu sebesar 0.346 . untuk indikator F18 memiliki nilai loading factor kurang dari 0.55 yaitu sebesar 0.306 . Jadi dapat disimpulkan bahwa pada tahap ini terdapat 6 (enam) indikator yang harus dikeluarkan dari proses factoring karena tidak memenuhi syarat loading.

\section{Tahap Kedua}

Setelah melalui tahap pertama, maka ditahap kedua ini dilakukan lagi pengujian analisis faktor dengan melibatkan variabel-variabel yang memenuhi syarat pada pengolahan data. Analisis faktor pada tahap ini melibatkan indikator-indikator yang memenuhi syarat pada pengolahan data. 
Analisis faktor pada tahap ini melibatkan indikator penelitian untuk mengetahui berapa banyak faktor yang terbentuk dari indikator tersebut.

Hasil pengujian analisis faktor tahap kedua dengan bantuan Program Komputer Statistik SPSS versi 16.0 dapat terlihat KMO and Barlett's Test pada Tabel berikut :

Tabel 7. Nilai KMO and Barlett's Test Tahap Kedua

\section{KMO and Bartlett's Test}

\begin{tabular}{|c|r|r|}
\hline \multicolumn{2}{|c|}{ Kaiser-Meyer-Olkin Measure of Sampling Adequacy. } & .889 \\
Bartlett's Test of Sphericity Df & Chi-Square & 638.067 \\
Sig. & 105 \\
\hline
\end{tabular}

Pada Tabel 7 di atas, diketahui bahwa nilai Kaiser-Meyer-Olkin Measureof Sampling Adequacy (MSA) sebesar 0.889 dengan signifikansi (0.000). Oleh karena angka MSA berada di atas 0,5 maka indikator yang ada dapat dilakukan analisis lebih lanjut. Selanjutnya setiap faktor dianalisis untuk mengetahui mana yang dapat diproses lebih lanjut dan mana yang harus dikeluarkan.

Pengujian selanjutnya pada tahap kedua ini adalah dengan memeriksa nilai Eigenvalues dari analisis faktor yang telah dilakukan. Eigenvalues pada tahap ini menunjukkan bahwa seluruh indikator yang dianalisis terbentuk faktor 4 (empat) faktor. Hal ini dapat dilihat berdasarkan Tabel Eigenvalues yang menunjukkan bahwa komponen yang memiliki nilai Eigenvalues diatas 1.00. Untuk lebih jelasnya nilai masing-masing Eigenvalues komponen dapat dilihat pada Tabel berikut:

Tabel 8. Nilai Eigenvalues Tahap Kedua

Total Variance Explained

\begin{tabular}{|c|c|c|c|c|c|c|c|c|c|}
\hline \multirow{2}{*}{ Component } & \multicolumn{3}{|c|}{ Initial Eigenvalues } & \multicolumn{3}{|c|}{$\begin{array}{c}\text { Extraction Sums of Squared } \\
\text { Loadings }\end{array}$} & \multicolumn{3}{|c|}{$\begin{array}{c}\text { Rotation Sums of Squared } \\
\text { Loadings }\end{array}$} \\
\hline & Total & \begin{tabular}{|c|}
$\%$ of \\
Variance
\end{tabular} & $\begin{array}{c}\text { Cumulative } \\
\%\end{array}$ & Total & $\begin{array}{c}\% \text { of } \\
\text { Variance }\end{array}$ & $\begin{array}{c}\text { Cumulative } \\
\%\end{array}$ & Total & $\begin{array}{c}\% \text { of } \\
\text { Variance }\end{array}$ & $\begin{array}{c}\text { Cumulative } \\
\%\end{array}$ \\
\hline 1 & 6.283 & 41.885 & 41.885 & 6.283 & 41.885 & 41.885 & 3.482 & 23.211 & 23.211 \\
\hline 2 & 1.324 & 8.830 & 50.714 & 1.324 & 8.830 & 50.714 & 2.730 & 18.199 & 41.409 \\
\hline 3 & 1.087 & 7.249 & 57.963 & 1.087 & 7.249 & 57.963 & 2.483 & 16.554 & 57.963 \\
\hline 4 & .924 & 6.163 & 64.126 & & & & & & \\
\hline 5 & .765 & 5.101 & 69.227 & & & & & & \\
\hline 6 & .751 & 5.010 & 74.236 & & & & & & \\
\hline 7 & .646 & 4.308 & 78.544 & & & & & & \\
\hline 8 & .599 & 3.996 & 82.540 & & & & & & \\
\hline 9 & .506 & 3.373 & 85.913 & & & & & & \\
\hline 10 & .466 & 3.105 & 89.018 & & & & & & \\
\hline 11 & .440 & 2.930 & 91.949 & & & & & & \\
\hline 12 & .370 & 2.464 & 94.413 & & & & & & \\
\hline 13 & .324 & 2.160 & 96.573 & & & & & & \\
\hline 14 & .288 & 1.923 & 98.496 & & & & & & \\
\hline 15 & .226 & 1.504 & 100.000 & & & & & & \\
\hline
\end{tabular}

Extraction Method: Principal Component Analysis. 
Berdasarkan data pada Tabel 8 di atas, diketahui bahwa terdapat 3 (tiga) faktor yang terbentuk pada analisis tahap kedua. Nilai Eigenvalues pada faktor 1 masih diatas 1.00 yaitu sebesar 6.283 , pada faktor 2 Nilai Eigenvalues juga masih diatas 1.00 yaitu sebesar 1.324, pada faktor 3 Nilai Eigenvalues masih diatas 1.00 yaitu sebesar 1.087, sedangkan pada faktor 4 dengan Nilai Eigenvalues sudah berada di bawah 1.00 yakni sebesar 0.924 sehingga proses factoring berhenti pada 3 (tiga) faktor saja.

Tahap selanjutnya adalah pengujian atas matriks faktor. Pengujian terhadap matriks faktor dilakukan dengan membandingkan nilai Component Matrix pada setiap indikator dengan nilai loading factor maka faktor tersebut dikeluarkan dari proses factoring karena indicator tidak dapat secara nyata membentuk sebuah faktor. Nilai loading factor atau pembatas (cut off point) agar sebuah indikator dapat secara nyata termasuk faktor, dari data 105 responden yang diperoleh oleh penelitian ini adalah sebesar 0.55 .

Untuk lebih jelasnya nilai matriks faktor yang dibandingkan dengan nilai loading factor sebesar 0.55 untuk secara nyata dapat termasuk sebuah faktor, dan dapat di liihat pada Tabel berikut:

Tabel 9. Komponen Matriks Tahap Kedua

\begin{tabular}{|l|r|r|r|}
\multicolumn{4}{|c|}{ Component Matrix ${ }^{\mathrm{a}}$} \\
\cline { 2 - 4 } & \multicolumn{3}{|c|}{ Component } \\
\hline $\mathrm{X} 1$ & .742 & .157 & \multicolumn{1}{c|}{-.085} \\
$\mathrm{X} 2$ & .775 & .021 & .109 \\
$\mathrm{X} 3$ & .661 & -.351 & -.159 \\
$\mathrm{X} 6$ & .650 & -.060 & .321 \\
$\mathrm{X} 7$ & .582 & -.069 & -.189 \\
$\mathrm{X} 10$ & .536 & .425 & .511 \\
$\mathrm{X} 11$ & .645 & .044 & .258 \\
$\mathrm{X} 12$ & .668 & -.475 & -.104 \\
$\mathrm{X} 14$ & .598 & -.171 & -.354 \\
$\mathrm{X} 15$ & .602 & -.437 & .099 \\
$\mathrm{X} 16$ & .722 & .112 & -.145 \\
$\mathrm{X} 17$ & .784 & -.080 & -.009 \\
$\mathrm{X} 19$ & .546 & .517 & -.309 \\
$\mathrm{X} 20$ & .562 & .501 & -.352 \\
$\mathrm{X} 21$ & .561 & .041 & .437 \\
\hline
\end{tabular}

Berdasarkan Tabel 9 di atas, dapat diketahui bahwa semua faktor dikatakan memenuhi syarat untuk memiliki nilai loading factor lebih dari 0.55

Tahap selanjutnya menganalisis Tabel Communalities, dimana pada dasarnya adalah jumlah varians dari suatu indikator mula-mula yang bisa dijelaskan oleh faktor yang ada. Berikut Tabel Communalities pada tahap ini sebagai berikut : 
Tabel 10. Communalities

Communalities

\begin{tabular}{|l|r|r|}
\hline & \multicolumn{1}{|c|}{ Initial } & \multicolumn{1}{|c|}{ Extraction } \\
\hline X1 & 1.000 & .582 \\
X2 & 1.000 & .612 \\
X3 & 1.000 & .585 \\
X6 & 1.000 & .529 \\
X7 & 1.000 & .379 \\
X10 & 1.000 & .728 \\
X11 & 1.000 & .485 \\
X12 & 1.000 & .683 \\
X14 & 1.000 & .513 \\
X15 & 1.000 & .563 \\
X16 & 1.000 & .555 \\
X17 & 1.000 & .621 \\
X19 & 1.000 & .661 \\
X20 & 1.000 & .691 \\
X21 & 1.000 & .507 \\
\hline
\end{tabular}

Berdasarkan Tabel 10 diatas, diketahui bahwa untuk indikator X1 (saran keluarga) memiliki nilai extraction sebesar 0.582 , hal ini berarti sekitar $58.2 \%$ varians dari $\mathrm{X} 1$ bisa dijelaskan oleh faktor yang terbentuk. Indikator X2 (saran teman-teman) memiliki nilai extraction sebesar 0.612, hal ini berarti sekitar $61.2 \%$ varians dari X2 bisa dijelaskan oleh faktor yang terbentuk. Indikator X3 (iklan melalui media TV) memiliki nilai extraction sebesar 0.585 , hal ini berarti sekitar $58.5 \%$ varians dari X3 bisa dijelaskan oleh faktor yang terbentuk. Indikator X6 (fitur yang canggih) memiliki nilai extraction sebesar 0.529, hal ini berarti sekitar 52.9\% varians dari X6 bisa dijelaskan oleh faktor yang terbentuk. Indikator X7 (mempunyai daya saing dengan produk lain) memiliki nilai extraction sebesar 0.379 , hal ini berarti sekitar $37.9 \%$ varians dari X7 bisa dijelaskan oleh faktor yang terbentuk. Indikator X10 (kualitas kamera unggul) memiliki nilai extraction sebesar 0.728, hal ini berarti sekitar $72.8 \%$ varians dari X10 bisa dijelaskan oleh faktor yang terbentuk. Indikator X11 (kualitas produk bagus) memiliki nilai extraction sebesar 0,485, hal ini berarti sekitar $48.5 \%$ varians dari X11 bisa dijelaskan oleh faktor yang terbentuk. Indikator X12 (promosi yang menyakinkan) memiliki nilai extraction sebesar 0.683 , hal ini berarti sekitar $68.3 \%$ varians dari X12 bisa dijelaskan oleh faktor yang terbentuk. Indikator X14 (harga terjangkau) memiliki nilai extraction sebesar 0.513, hal ini berarti sekitar 51.3\% varians dari X14 bisa dijelaskan oleh faktor yang terbentuk. Indikator X15 (bentuk fisik yang menarik) memiliki nilai extraction sebesar 0.563 , hal ini berarti sekitar $56.3 \%$ varians dari X15 bisa dijelaskan oleh faktor yang terbentuk. Indikator X16 (desain produk mewah) memiliki nilai extraction sebesar 0.555 , hal ini berarti sekitar $55.5 \%$ varians dari X16 bisa dijelaskan oleh faktor yang terbentuk. Indikator X17 (memiliki service center/layanan konsumen) memiliki nilai extraction sebesar 0.621 , hal ini berarti sekitar $62.1 \%$ varians dari X17 bisa dijelaskan oleh faktor yang terbentuk. Indikator X19 (nama produk yang unik dan mudah di ingat) memiliki nilai extraction sebesar 0.661, hal ini berarti sekitar 66.1\% varians dari X19 bisa dijelaskan oleh faktor yang terbentuk. Indikator X20 (ikut trend saat ini) memiliki nilai extraction sebesar 0.691, hal ini berarti sekitar $69.1 \%$ varians dari X20 bisa dijelaskan oleh faktor yang terbentuk. Indikator X21 
(kesesuaian antara harga dan kualitas) memiliki nilai extraction sebesar 0.507 , hal ini berarti sekitar $50.7 \%$ varians dari X21 bisa dijelaskan oleh faktor yang terbentuk.

Setelah melalui tahap kedua diketahui bahwa nilai KMO and Barlett's Test diatas 0.5 dan nilai Komponen Matriks diatas angka loading factor sebesar 0.55, dimana dapat diartikan bahwa keseluruhan indikator telah dikatakan layak atau memenuhi syarat.

Pada tahap ini terbentuk juga faktor, setelah dilakukan pengujian analisis faktor dengan melihat nilai Eigenvalues yang terbentuk yaitu diatas nilai 1.00. Maka selanjutnya adalah memeriksa faktor-faktor yang memenuhi syarat nilai loading 0.55 dengan indikator pembentuknya pada hasil pengujian analisis faktor dengan melihat Tabel Rotated Component Matrix sebagai berikut :

Tabel 11. Rotated Component Matrix

Rotated Component Matrix ${ }^{\mathrm{a}}$

\begin{tabular}{|l|r|r|r|}
\hline & \multicolumn{3}{|c|}{ Component } \\
\cline { 2 - 4 } & 1 & 2 & 3 \\
\hline X1 & .404 & .383 & .521 \\
X2 X3 & .469 & .526 & .341 \\
X6 & .726 & .165 & .176 \\
X7 & .386 & .607 & .110 \\
X10 & .485 & .160 & .345 \\
X11 & .080 & .802 & .280 \\
X12 & .327 & .577 & .212 \\
X14 & .803 & .186 & .065 \\
X15 & .611 & .015 & .372 \\
X16 & .677 & .319 & .051 \\
X17 & .439 & .314 & .513 \\
X19 & .577 & .414 & .341 \\
X20 & .084 & .174 & .790 \\
X21 & .117 & .145 & .810 \\
\hline
\end{tabular}

Extraction Method: Principal Component Analysis. Rotation Method: Varimax with Kaiser Normalization. ${ }^{a}$ Rotation converged in 6 iterations.

Berdasarkan Tabel 11 di atas dapat disimpulkan bahwa dari 15 variabel yang dianalisis terdapat 1 variabel memiliki nilai loading kurang dari 0.55 yaitu variabel X7 (mempunyai daya saing dengan produk lain) dengan nilai 0,485 sehingga variabel ini dikeluarkan dari proses analisis karena tidak layak menjadi pembentukan sebuah faktor.

Proses selanjutnya dari analisis faktor adalah proses penamaan faktor dari faktor yang dikatakan layak setelah melewati beberapa hasil uji. Pada proses penamaan ini dilakukan secara berurutan dari faktor yang memiliki nilai Eigenvalues terbesar hingga terkecil.

Secara keseluruhan dari 21 indikator yang telah diolah dengan menggunakan uji kesahilan butir hingga uji analisis faktor menghasilkan faktor yang memenuhi persyaratan loading factor sebesar 0.55 . Secara ringkas, faktor-faktor yang terbentuk dan indikator pembentuknya dapat dilihat pada Tabel berikut : 
Tabel 12 Ringkasan Faktor dan Indikator yang Membentuknya

\begin{tabular}{ccc}
\hline Faktor & Indikator & Loading \\
& X12 Promosi yang menyakinkan & 0.803 \\
Promosi dan & X3 Iklan media TV & 0.726 \\
Harga & X15 Bentuk fisik yang menarik & 0.677 \\
& X14 Harga terjangkau & 0.611 \\
& X17 Memiliki service center/layanan konsumen & 0.577 \\
\hline Kualitas & X10 Kualitas kamera unggul & 0.802 \\
Produk & X21 Kesesuaian antara harga dan kualitas & 0.672 \\
& X6 Fitur yang canggih & 0.607 \\
& X11 Kualitas produk bagus & 0.577 \\
X2 Saran teman-teman & 0.526 \\
\hline \multicolumn{3}{c}{ X20 Ikut trend saat ini 0.810 } \\
Gaya Hidup & X1 Saran keluarga 0.521 \\
& X16 Desain produk mewah & 0.513 \\
& \\
\hline
\end{tabular}

\section{Faktor 1 : Promosi dan Harga}

Faktor pertama memiliki nilai Eigenvalues sebesar 6.283. faktor ini terbentuk dari 5 (lima) indikator, yaitu X3 (iklan media TV) dengan faktor loading sebesar 0.726, X12 (promosi yang menyakinkan) dengan faktor loading sebesar 0.803, X14 (harga terjangkau) dengan faktor loading sebesar 0.611, X15 (bentuk fisik yang menarik) dengan faktor loading sebesar 0.677, X17 (memiliki service center/layanan konsumen) dengan faktor loading sebesar 0.577. Diberi nama Faktor Produk yang diperoleh dari indikator yang memiliki faktor loading tertinggi yang mewakili faktor tersebut, yaitu indikator X12 (promosi yang menyakinkan) dengan faktor loading 0.803 .

Promosi merupakan kegiatan pemasaran dan penjualan dalam rangka menginformasikan dan mendorong permintaan terhadap produk, jasa , dan ide dari perusahaan dengan cara memengaruhi para konsumen agar mau membeli produk dan jasa yang dihasilkan oleh perusahaan.

Promosi adalah segala macam bentuk komunikasi persuasi yang dirancang untuk menginformasikan pelanggan tentang produk atau jasa dan untuk memengaruhi mereka agar membeli barang atau jasa tersebut yang mencakup publisitas, penjualan, perorangan, dan periklanan. Zimmerer (2002). Suatu perusahaan didalam menentukan alat-alat promosi harus memperhatikan komponen-komponen yang ada di dalam bauran promosi yang terdiri dar 4 komponen yaitu :

1. Advertising (periklanan)

Periklanan adalah segala bentuk penyajian dan promosi bukan pribadi mengenai gagasan, barang, atau jasa yang dibayar oleh sponsor tertentu.

2. Publisitas (publikasi)

Publisitas merupakan bagian dari fungsi yang lebih luas yaitu hubungan masyarakat dan meliputi usaha-usaha untuk menciptakan dan mempertahankan hubungan yang menguntungkan antara organisasi, dengan masyarakat, dan juga dengan calon pembeli.

3. Sales promotion (promosi penjualan)

Promosi penjualan merupakan kegiatan promosi selain periklanan, personal selling, maupun publisitas. Kegiatan-kegiatan yang termasuk dalam promosi penjualan antara lain : peragaan, pertunjukan, pameran, demonstrasi, dan sebagainya.

4. Direct marketing

Direct marketing adalah suatu system pemasaran interaktif yang menggunakan satu atau lebih media periklanan untuk respon yang terukurdan atau transaksi dimanapun 
Harga adalah sesuatu yang dibutuhkan untuk mendapatkan suatu kombinasi antara pelayanan ditambah produk dengan membayar jumlah uang yang sudah menjadi patokan. (Basu Swastha \& Irawan, 2005).

Penetapan suatu harga produk atau jasa tergantung dari tujuan perusahaan atau penjual yang memasarkan produk tersebut yaitu :

1. Penetapan harga suatu produk memiliki tujuan untuk mencapai target perusahaan untuk memperoleh penghasilan serta mendapatkan target investasi yang sudah ditentukan presentase keuntungannya, sehingga untuk memenuhi hal tersebut diperlukan adanya penetapan harga pasti dari suatu produk yang telah di produksi perusahaan.

2. Fungsi penetapan harga yang kedua merupakan hal yang harus diperhatikan untuk kestabilan harga suatu produk.

3. Penetapan harga dilakukan oleh perusahaan untuk mempertahankan produk dalam peredaran pasar, sehingga produk tetap dapat bertahan dipasaran.

4. Penetapan harga harus dilakukan untuk mencegah terjadinya persaingan dengan perusahaan lain yang memiliki produk yang hampir sama.

5. Perusahaan menetapkan harga untuk menentukan laba yang akan didapat oleh perusahaan agar perusahaan tetap dapat memproduksi suatu barang yang akan dipasarkan

\section{Faktor 2 : Kualitas Produk}

Faktor kedua memiliki nilai Eigenvalues sebesar 1.324. Faktor ini terbentuk dari 5 (lima) indikator, yaitu X2 (saran teman-teman) dengan faktor loading sebesar 0.526, X6 (fitur yang canggih) dengan faktor loading sebesar 0.607, X10 (kualitas kamera unggul) dengan faktor loading sebesar 0.802, X11 (kualitas produk bagus) dengan faktor loading sebesar 0.577, X21 (kesesuaian antara harga dan kualitas) dengan faktor loading sebesar 0.672. Diberi nama Faktor Produk yang diperoleh dari indikator yang memiliki faktor loading tertinggi yang mewakili faktor tersebut, yaitu indikator X10 (kualitas kamera unggul) dengan faktor loading 0.802 .

Menurut Kotler \& Amstrong (2008) Kualitas produk adalah kemampuan suatu produk untuk melaksanakan fungsinya meliputi, daya tahan keandalan, ketepatan kemudahan operasi dan perbaikan, serta atribut bernilai lainnya. Untuk mencapai kualitas produk yang diinginkan maka diperlukan suatu standarisasi kualitas. Cara ini dimaksudkan untuk menjaga agar produk yang dihasilkan memenuhi standar yang telah ditetapkan sehingga konsumen tidak akan kehilangan kepercayaan terhadap produk yang bersangkutan. Pemasar yang tidak memperhatikan kualitas produk yang ditawarkan akan menanggung tidak loyalnya konsumen sehingga penjualan produknya pun cenderung menurun. Jika pemasar memperhatikan kualitas bahkan diperkuat dengan periklanan dan harga yang wajar maka konsumen tidak akan berpikir panjang untuk melakukan pembelian terhadap produk.

\section{Faktor 3 : Gaya Hidup}

Faktor kedua memiliki nilai Eigenvalues sebesar 1.087. Faktor ini terbentuk dari 4 (empat) indikator, yaitu X1 (saran keluarga) dengan faktor loading sebesar 0.521, X16 (desain produk mewah) dengan faktor loading sebesar 0.513, X19 (nama produk yang unik dan mudah di ingat) dengan faktor loading sebesar 0.790, X20 (ikut trend saat ini) dengan faktor loading sebesar 0.810. Diberi nama Faktor Produk yang diperoleh dari indikator yang memiliki faktor loading tertinggi yang mewakili faktor tersebut, yaitu indikator X20 (ikut trend saat ini) dengan faktor loading 0.802.

Gaya hidup (lifestyle) adalah bagian dari kebutuhan sekunder manusia yang bisa berubah bergantung zaman atau keinginan seseorang untuk mengubah gaya hidupnya. Istilah gaya hidup pada awalnya dibuat oleh psikolog Austria, Alfred Adler, pada tahun 1929. Pengertiannya yang lebih luas, sebagaimana dipahami pada hari ini, mulai digunakan sejak 1961. Gaya hidup bisa dilihat dari cara berpakaian, kebiasaan dan lain-lain. Menurut kotler (2002) Gaya hidup adalah pola hidup seseorang di dunia yang di ekspresikan dalam aktivitas, minat, dan opininya. Gaya hidup menggambarkan "keseluruhan diri seseorang" dalam berinteraksi dengan lingkungannya. 
Memang benar bahwa faktor-faktor diatas adalah faktanya, karena selama peneliti melakukan penelitian terhadap smartphone merek OPPO ini peneliti mendapatkan fakta bagaimana promosi yang dilakukan melalui berbagai media, harganya yang juga terjangkau, dan bentuk fisiknya yang menarik serta dilengkapi dengan fitur-fitur yang canggih dengan keunggulan kualitas kameranya dan sesuai dengan perkembangan zaman saat ini. Hal inilah yang membuat konsumen memilih Smartphone merek OPPO ini.

\section{KESIMPULAN DAN SARAN}

\section{Kesimpulan}

Berdasarkan hasil dan pembahasan penelitian, diperoleh kesimpulan dalam penelitian ini adalah sebagai berikut :

Hasil analisis faktor yang dilakukan dengan melalui tahapan-tahapan pengujian dengan menggunakan 21 indikator dan diperoleh data dari 105 responden yang digunakan sebagai sampel penelitian, ditemukan bahwa ada 3 (tiga) faktor yang dipertimbangkan konsumen memutuskan membeli dan menggunakan Smartphone merek OPPO di kecamatan palu selatan, yaitu :

1. Promosi dan Harga

Faktor ini memiliki 5 (lima) indikator dengan nilai Eigenvalues sebesar 6.283. dengan masingmasing indikatornya adalah X3 (iklan media TV), X12 (promosi yang menyakinkan), X14 (harga terjangkau), X15 (bentuk fisik yang menarik), X17 (memiliki service center/layanan konsumen).

2. Kualitas Produk

Faktor ini memiliki 5 (lima) indikator dengan nilai Eigenvalues sebesar 1.324. dengan masingmasing indikatornya adalah X2 (saran teman-teman), X6 (fitur yang canggih), X10 (kualitas kamera unggul), X11 (kualitas produk bagus), X21 (kesesuaian antara harga dan kualitas).

3. Gaya Hidup

Faktor ini memiliki 5 (lima) indikator dengan nilai Eigenvalues sebesar 1.087. dengan masingmasing indikatornya adalah X1 (saran keluarga), X16 (desain produk mewah), X19 (nama produk yang unik dan mudah di ingat), X20 (ikut trend saat ini).

\section{Saran}

Smartphone merek OPPO adalah salah satu dari sekian banyak produk Smartphone yang ada dengan berbagai macam jenis dan model yang bervariasi. Dalam hal ini penulis ingin memberikan beberapa saran untuk perusahaan OPPO agar kedepannya bisa lebih berkembang dan maju, yaitu sebagai berikut:

1. Disarankan kepada perusahaan OPPO agar lebih memperbaiki dan meningkatkan kualitas produknya, agar meningkat pula konsumen yang akan menggunakan smartphone merek OPPO ini, karena berdasarkan hasil penelitian ini faktor-faktor yang dominan dipertimbangkan konsumen memutuskan membeli dan menggunakan smartphone merek OPPO yaitu dari kualitas produknya, promosi dan kecanggihana fiturnya yang sesuai dengan trend gaya hidup saat ini.

2. Disarankan kepada peneliti selanjutnya yang tertarik untuk meneliti dengan objek yang sama agar lebih memperhatikan indikator-indikator yang dipertimbangkan dan tahapan dalam mengolah data penelitian, agar hasil penelitian yang dihasilkan lebih maksimal.

\section{REFERENSI}

Basu Swastha \& Irawan, (2005) . Manajemen Pemasaran Modern. Liberty: Yogyakarta

Kotler, P. (2005). Manajemen Pemasaran. Edisi kesebelas Jilid 1. PT Indeks Kelompok Gramedia: Jakarta

Kotler, P. (2002). Manajemen Pemasaran. Edisi 9 Jilid 1dan 2. PT.Prehalindo: Jakarta

Kotler, P. \& Keller, K. L. (2009). Manjemen Pemasaran. Edisi ketigabelas. Erlangga: Jakarta

Malhotra, N.K. (2005). Riset Pemasaran Pendekatan Terapan. Edisi Keempat Jilid 1. PT Indeks: Jakarta 
Ndari, TW.

Sugiyono, (2014). Metode Penelitian Bisnis. Cv Alfabeta: Bandung

Windusarah, D. A. (2015). Pengaruh Bauran Promosi Terhadap Keputusan Pembelian OPPO Smartphone. Jurnal Manajemen Unud, 4(12). 